Правильно застосувавши їх, процес навчання стає цікавим і неповторним дійством. Про це свого часу наголошував і В. О. Сухомлинський, настанови якого і сьогодні, на початку XX століття, не втрачають своєї актуальності.

Запропоновані нами у статті положення видатного педагога про значимість міжпредметних зв'язків важливі насамперед тому, що орієнтують учителів на їх організацію, поетапне формування міжпредметних понять, використання проблемних запитань і задач, а як наслідок - сприяють розвитку в здобувачів освіти таких важливих якостей, як спостережливість, допитливість, уміння самостійно аналізувати явища навколишнього світу.

\section{СПИСОК ВИКОРИСТАНОЇ ЛІТЕРАТУРИ}

1. Барановська О. Модернізація змісту профільного навчання в світлі міжпредметної інтеграції / О. Барановська // Директор школи, ліцею, гімназії. 2015. - № 5. - С. 94-100.

2. Бевз В. Г. Міжпредметні зв'язки як необхідний елемент предметної системи навчання / В. Г. Бевз // Математика в школі. - 2003. - № 6. - С. 11-15.

3. Гончаренко С. У. Український педагогічний словник / С. У. Гончаренко. - Київ : Либідь, 1997. - 376 с.
4. Остраус М. Ю. Реалізація міжпредметних зв'язків у педагогічній спадщині Василя Олександровича Сухомлинського [Електронний ресурс]. URL: http://intkonf.org/ostraus-yu-m-realizatsiya-mizh predmetnih-zvyazkiv-v-pedagogichniy-spadschinivasilya-oleksandrovicha-suhomlinskogo/ (дата звернення: 20.06.2019).

5. Савченко О. Я. Міжпредметні зв'язки як ресурс реалізації компетентнісного підходу на уроках літературного читання / О. Я. Савченко // Український педагогічний журнал. - 2017. - № 2. - С. 48-57.

6. Сухомлинський В. О. Розмова з молодим директором школи / В. О. Сухомлинський // Вибрані твори : в 5 т. - К. : Рад. школа, 1976. - Т. 1. - С. 393-629.

7. Сухомлинський В. О. Сто порад учителеві / В. О. Сухомлинський // Вибрані твори : в 5 т. - К. : Рад. школа, 1979. - Т. 2. - С. 419-655.

8. Сухомлинський В. О. Павлиська середня школа / В. О. Сухомлинський // Вибрані твори : в 5 т. К. : Рад. школа, 1977. - Т. 4. - С. 2-640.

9. Сухомлинський В. О. Проблеми виховання всебічно розвиненої особистості / В. О. Сухомлинський // Вибрані твори : в 5 т. - К. : Рад. школа, 1976. T. 1. - C. 5-208.

Дата надходження до редакиї: 20.08.2019 р.
УДК 37.091.4(092)

DOI: $10.37026 / 2520-6427-2019-99-3-15-20$

\section{Олександр МІХНО,}

кандидат педагогічних наук, стариий науковий співробітник відділу наукової реферативної та аналітичної інформації у сфері освіти Державної науково-педагогічної бібліотеки Украӥни імені В. О. Сухомлинського, м. Київ

\title{
АКОРДИ ТА АКЦЕНТИ БІОГРАФІЇ ВАСИЛЯ СУХОМЛИНСЬКОГО (методичні поради для вчителя за книгою Бориса Тартаковського «Повість про вчителя Сухомлинського»)
}

\begin{abstract}
У статті на основі аналізу змісту та історіі написання твору Б. Тартаковського «Повість про вчителя Сухомлинського» подано методичні рекомендації та поради для педагогів з метою вивчення біографії Василя Сухомлинського. Обгрунтовано доиільність використання в ході вивчення біографіi видатного педагога акордної системи навчання, щзо широко застосовувалася у 20-х роках XX століття. У вигляді таблииі представлено основні акорди та акиенти біографії Василя Сухомлинського.

Ключові слова: Василь Сухомлинський, біографія, акордна система навчання, методичні поради.
\end{abstract}

В статье на основе анализа содержания и истории написания произведения Б. Тартаковского «Повесть об учителе Сухомлинском» представлены методические рекомендации и советы для педагогов с иелью изучения биографии Василия Сухомлинского. Обоснована ичелесообразность использования в ходе изучения биографии выдаюшегося педагога аккордной системы обучения, которая широко применялась в 20-х годах XX века. $B$ виде таблииь представлены основные аккорды и акиенты биографии Василия Сухомлинского.

Ключевые слова: Василий Сухомлинский, биография, аккордная система обучения, методические советь. 
In the article, based on the consideration of the content and history of writing the work by Boris Tartakovsky "The Tale of Teacher Sukhomlinsky», the methodical recommendations to the teacher for the lesson of studying the biography of Vasyl Sukhomlinsky are given. It has been substantiated that the teacher should not reduce the information about the life and creative way of V. Sukhomlinsky to the biographical frame: he was born, studied, defended his thesis, published so many works, etc., since in this approach, the person is not interesting for the students. It is recommended to present the most interesting facts from the teacher's life, which will help students to imagine and capture the image of $V$. Sukhomlinsky in their memory through bright associations. The expediency of use in the course of studying the biography of the teacher of the chord system of teaching, which was widely used in the 1920s in vocational education, has been substantiated. It is emphasized that the best way to study the biography of a writer or a cultural and educational figure is the story of the teacher with the elements of the conversation, and in upper secondary school, an interactive lecture with the use of modern multimedia technologies. The main chords and accents of V. Sukhomlinsky's biography are presented in the form of a table that the teacher can use creatively, by reducing or supplementing it. In the course of studying the biography of Vasyl Sukhomlinsky it is recommended to use the memoirs of the teacher's daughter, Olga Vasylivna Sukhomlinskaya «My Father».

Key words: Vasyl Sukhomlinsky, biography, chord system of teaching.

Постановка проблеми. Найкращим методом вивчення біографії письменника чи історичного (освітнього, культурного) діяча в школі є, на нашу думку, розповідь учителя з елементами бесіди, а в старших класах - інтерактивна лекція з використанням сучасних мультимедійних технологій. Невиправданим вважаємо поширене нині тестування за біографічними даними, оскільки особистість шляхом тестування не розкривається, не зацікавлює учнів, і навіть інколи відштовхує від постаті письменника. Такий популярний сьогодні метод, як підготовка учнями доповідей (повідомлень) за заздалегідь поданим планом із вказаними фактами біографії (завдання випереджувального характеру), також, на наш погляд, використовувати не варто. Підготовка таких доповідей вимагає чимало часових затрат, контролю і коригування з боку вчителя. Крім того, учні, як правило, використовують для підготовки власних повідомлень інформацію 3 мережі Інтернет (насамперед Вікіпедії), інформація 3 якої зазвичай не вирізняється емоційністю, зокрема $€$ банальним набором розміщених у хронологічній послідовності дат, а інколи ще й суперечливою та недостовірною.

У ході вивчення біографії Василя Сухомлинського, на нашу думку, використання розповіді та лекції $\epsilon$ оптимальним ще й $з$ огляду на те, що сам педагог уважав слово вчителя найважливішим педагогічним інструментом, про що свідчать його численні афоризми, як-от: «Слово - найтонший і найгостріший інструмент, яким ми, вчителі, повинні вміло доторкатися до сердець наших вихованців», «У слові акумулюються відносини між людьми, слово виявляє ідею, а ідея - стовповий корінь виховання»,
«Коли слово хвилює дитину своєю неповторною красою, воно назавжди запам'ятовується» [7, с. 80-81].

Аналіз наукових досліджень i публікацій. Життєвому i творчому шляху Василя Сухомлинського (1918-1970) присвячено низку поетичних та художніх творів, зокрема драматична поема I. Драча «Дума про вчителя» (1976), поезії В. Базилевського «В. О. Сухомлинському», В. Терена «Вулиця Сухомлинського», Ю. Мальованого «Видіння», а також прозові - «Повість про вчителя Сухомлинського» Б. Тартаковського (1972), «Добротворець» І. Цюпи (1971) та ін.

Серед згаданих творів варто виокремити повість Бориса Тартаковського, що вирізняється як особливостями створення, так і специфікою побудови. Саме цей твір ми рекомендуємо використати вчителям під час уроку вивчення біографії В. Сухомлинського.

Мета статті - на основі аналізу «Повісті про вчителя Сухомлинського» Бориса Тартаковського запропонувати методичні рекомендації та поради вчителям до уроку вивчення біографії Василя Сухомлинського.

Виклад основного матеріалу. У чинних навчальних програмах творчість В. О. Сухомлинського та його постать розглядається у у 2-4-х та 5-му клаcax, а як наслідок - біографічні відомості не мають бути переобтяжені датами і містити інформацію та поняття, доступні для розуміння дітьми означеного віку $[1 ; 2]$.

Наголосимо, що постать Василя Сухомлинського надзвичайно багатогранна, творча спадщина якого воістину невичерпна, тож у межах уроку висвітлити іiі у всій повноті, звісно ж, неможливо. Тому пропонуємо вчителю оригінальний принцип побудови уроку вивчення біографії, в основу якого покладено акордну систему навчання, що виникла і широко застосовувалася у 20 -х роках XX ст.

Акордна система - це своєрідний синтез предметної і комплексної систем. Від предметної системи вона взяла систематичність і визначеність навчальної програми, а від комплексної - органічний зв'язок того, що вивчається, з елементами тематичності. Навчальний матеріал за цією системою вкладався у три акорди, тобто три найважливіші підтеми. Основна мета акордної системи - не лише дати знання 3 певної теми, а й формувати світогляд. Дана система у 1920-х роках застосовувалася у професійній освіті [8, с. 130-131], а сам термін «акорд», очевидно, походить із музичної сфери. Нагадаємо, що «акорд» у музиці - це поєднання трьох і більше тонів, які звучать одночасно і сприймаються як ціле, тобто як щось більше ніж сума окремих тонів.

Якщо біографію розбити на акорди, то кожен із них має складатися, як мінімум, із трьох підтем (акцентів), однак їх може бути і більше. Пропонуємо ознайомитися із акордами та акцентами біографії Василя Сухомлинського, які ми представили у вигляді таблиці. Означений матеріал учитель може використовувати як основу своєї розповіді, конкретизуючи акценти розгорнутою інформацією. Зауважимо, що дана таблиця спрямована на творче використання, тобто вчитель може використовувати ії у повному обсязі або ж скорочувати чи доповнювати власними акордами й акцентами. 
Акорди та акценти біографії В. Сухомлинського

\begin{tabular}{|c|c|}
\hline Акорди & Акценти \\
\hline \multirow[t]{3}{*}{ Дитинство } & дідусь Омелян (книги) і бабуся Марія (казки) \\
\hline & батьки Олександр Омелянович і Оксана Овдіївна \\
\hline & мальовнича природа, музика (майстерно грав на власноруч виготовленій із бузини сопілці) \\
\hline \multirow[t]{3}{*}{ Навчання } & сільська школа \\
\hline & учительські інститути (Кременчук, Полтава) \\
\hline & викладачі, студентський побут \\
\hline \multirow[t]{3}{*}{ Війна } & поранення (1942) \\
\hline & госпіталь \\
\hline & Ува (Удмуртія на півночі Росії; вчитель, директор) \\
\hline \multirow{3}{*}{$\begin{array}{l}\text { Педагогічна } \\
\text { діяльність }\end{array}$} & учитель української мови і літератури \\
\hline & директор Павлиської школи (понад 22 роки, із 1948) \\
\hline & науковець (кандидат педагогічних наук) \\
\hline \multirow[t]{3}{*}{ Сім'я } & квартира знаходилася у приміщенні школи \\
\hline & дружина Ганна Іванівна \\
\hline & діти Сергій та Ольга \\
\hline $\begin{array}{l}\text { Педагогічна } \\
\text { система }\end{array}$ & $\begin{array}{l}\text { взаємовідносини вчителя і учнів } \rightarrow \text { уроки серед природи } \rightarrow \text { роль казки у навчанні й вихо- } \\
\text { ванні } \rightarrow \text { трудове виховання } \rightarrow \text { естетичне, зокрема музичне, виховання } \rightarrow \text { педагогічний } \\
\text { оптимізм (віра в учня, віра в людину) } \rightarrow \text { «школа радості» } \rightarrow \text { психологічний семінар для } \\
\text { вчителів } \rightarrow \text { батьківська школа (заняття для батьків) } \rightarrow \text { навчання малоздібних учнів із серйоз- } \\
\text { ними недоліками пам’яті } \rightarrow \text { виховання культури бажань } \rightarrow \text { сімейна педагогіка (основи шлюбу, } \\
\text { сім'ї - спеціальні уроки для старшокласників) } \rightarrow \text { i, зрештою, головна тема як завершальний } \\
\text { акорд - виховання справжньої людини (етичні правила виховання справжньої людини) }\end{array}$ \\
\hline \multirow[t]{3}{*}{ Письменник } & вірші (почав писати і друкуватися ще в юнацькому віці, перша публікація - у 15 років[5]) \\
\hline & педагогічні твори, насамперед «Серце віддаю дітям», публіцистика - численні статті в газетах \\
\hline & художні мініатюри (казки, оповідання, притчі) - понад 1500 \\
\hline \multirow[t]{3}{*}{$\begin{array}{c}\text { Смерть } \\
\text { і безсмертя }\end{array}$} & $\begin{array}{l}\text { Педагогічно-меморіальний музей В. Сухомлинського; шкільна садиба; місце останнього } \\
\text { спочинку }\end{array}$ \\
\hline & дослідження і використання спадщини; видання творів \\
\hline & заклади, вулиці, які носять ім'я В. Сухомлинського \\
\hline
\end{tabular}

Беручи за основу означену вище таблицю, вчителю не варто зводити інформацію про життєвий і творчий шлях В. Сухомлинського до біографічного фрейму: народився, навчався, захистив дисертацію, опублікував стільки-то праць та ін. Зазвичай за такого підходу особистість якраз і залишається загадкою. Натомість рекомендуємо подати найцікавіші факти із життя педагога, які допоможуть школярам уявити i зафіксувати в пам'яті образ видатного педагога через яскраві асоціації. Найкращим джерелом інформації про Василя Олександровича, яке в образній, доступній школярам формі розкриває особистість, це, на нашу думку, - художні твори. Зокрема, принагідно можна ознайомити школярів із книгою «Повість про вчителя Сухомлинського» Б. Тартаковського.

Борис Семенович Тартаковський (1912-1985), український письменник (писав російською мовою). Народився 2 липня 1912 р. у Києві. Закінчив Київський університет. Журналіст, учасник Другої світової війни. Після війни працював відповідальним секретарем української республіканської газети «Комсомольское знамя». Автор близько 20-ти повістей, численних нарисів, оповідань.

Уперше книгу «Повість про вчителя Сухомлинського» опублікувало наприкінці 1972 року в Москві видавництво «Молодая гвардия». Вона вийшла накладом 100 тисяч примірників [9]. Одні$\epsilon ю 3$ особливостей оформлення книги $є$ наявність 24 фотографій, розміщених у спеціальній вкладці.
Крім фото, своєрідною є і структура книги: видання містить цікаво оформлені вставки під назвою «З магнітної стрічки», якими розпочинається кожна із 16 глав повісті. Фактично, це пряма мова Василя Сухомлинського, тобто розгорнуті цитати на теми навчання і виховання.

Для радянського часу, тим більше для подібних видань, це було нетипово, тому цей підхід цілком можна назвати новаторством. Але це не було винаходом Б. Тартаковського. Подібний принцип побудови публікацій, зокрема біографічних статей, нині у нас дуже популярний як у друкованих, так і в електронних публікаціях (зокрема, йдеться про лонгрід). Зародився цей жанр у західних країнах, де широко використовувався у 1960-х роках переважно у журнальних виданнях. На нашу думку, Б. Тартаковський, який як журналіст часто бував за кордоном (Греція, Бельгія, Єгипет, Індія, Італія, Туреччина, Франція та ін.), досить вдало використав його у своїй книзі.

Струнка композиція твору склалася не одразу. У робочих матеріалах Б. Тартаковського, що зберігаються у Центральному державному архіві-музеї літератури і мистецтв України (ЦДАЛМУ), знаходимо варіант повісті із численними помітками автора, закресленими і доданими рядками, вставками тощо. Не увійшов до остаточної редакції роману і кумедний епізод з інспектором Онуфріївського районного відділу освіти В. Гарбузом, який завітав у гості до родини Сухомлинських. Він у присутності Василя Олександровича запитав у маленької Олі, чи знає вона 
якісь вірші напам'ять, і дівчинка почала читати свого улюбленого «Ходить гарбуз по городу....». Дорослі засміялися [12, арк. 139-141]. Ця комічна ситуація ілюструє ставлення В. Сухомлинського до гумору, про який педагог писав: «...почуття гумору розвиває гостроту, пильність бачення світу» [3]. У житті Василь Олександрович любив і цінував гумор. Це підтверджує і О. Сухомлинська у спогаді «Мій батько»: «...у нього завжди була усмішка в очах... [він] любив жарти і сам умів дотепно жартувати» [4].

Вилучено 3 повісті й рядки Т. Шевченка, які цитує С. Чавдаров, говорячи про важливість визрівання педагогічних ідей. Звертаючись до Василя Сухомлинського, Сава Христофорович, на підтвердження своєї думки, каже:

«Пам'ятаєте -

Неначе цвяшок, в серце вбитий,

Оцю Марину я ношу.

Давно б списать несамовиту,

Так що ж? Сказали б, що брешу.

- Це із Шевченкової «Марини» [12, арк. 133].

Розпочинається повість із від’ізду В. Сухомлинського з рідного дому на навчання в Кременчук, далі вплітаються спогади про діда (його любов до читання і подаровані книги) і бабусю (розповідь казок). Оповідь розгортається перед читачем пластами (кадрами): студентські роки в Кременчуці та Полтаві, початок педагогічної діяльності вчителем-словесником, завучем, війна, поранення, госпіталь, Ува, повернення в Україну, Павлиська школа. Переконані, що відсутність дат є перевагою, адже це - художній твір.

Мабуть, кожен учитель, готуючись до уроку за книгою Б. Тартаковського, зверне увагу на якісь особливі деталі, близькі й зрозумілі саме йому. На наш погляд, промовистими штрихами до образу В. Сухомлинського $\epsilon$, наприклад, такі:

а) роль дідуся $і$ бабусі в житті дитини - у книзі вміщено епізод із дитячих років Василя Олександровича, коли помер його дідусь. У спадок від нього Василько отримав дві охайно перев'язані пачки книг. Онук відразу ж пригадав ті солодкі хвилини, коли старенький читав йому ці книжки. Через кілька днів хлопчик отримав ще один подарунок, але вже від батька, - красиву скриньку. Батько власноруч змайстрував їі для того, щоб син у ній зберігав дідусеві книги: повісті Івана Франка «Воа Constrictor» i «Захар Беркут», «Тарас Бульба» Миколи Гоголя, багатотомний, рідкісний у ті роки Достоєвський, оповідання Короленка, вірші Лесі Українки. Перш ніж скласти їх у скриньку, Василько так само, як і його покійний дідусь, обережно кожну гладив, ніби пестив їх. Обережно склавши книжки в скриньку, Василько в ту хвилину відчув себе найбагатшою людиною на всій Полтавщині [10, с. 14-15];

б) уміння майстерно грати на власноруч виготовленій із бузини сопілці - таких фактів у книзі, поданих у художній формі, чимало, що допомагає створити цілісний образ В. Сухомлинського;

в) автор надзвичайно ретельно підійшов до тих частин книги, які розкривають становлення особистості В. Сухомлинського, адже характер будь-якої, абстрактної, людини, формування ії̈ світогляду закладаються саме в дитинстві, юності, в студентські роки. Тут чи не найважливіше значення має взаємовплив конкретної людини й зовнішнього середовища, в якому вона проживає (спілкування, лекції вчителів, товариські взаємини, родинні зв'язки, одруження тощо); г) вплив війни з ї̈ жахами, перебування в госпіталі остаточно утвердили переконання В. Сухомлинського в тому, що життя - найбільша цінність, остаточно ствердилися його педагогічні ідеї і бажання втілити їх (зокрема йдеться про уроки мислення на природі, які він почав проводити ще в перші роки вчителювання);

г) духовний світ головного героя «Повісті...» представлено назвами книжок, історичних подій, іменами, цитатами. Класики педагогічної думки, української, російської, західноєвропейських літератур (особливо німецької), видатні історичні постаті, філософи, психологи, вчені, народна пісня, віршовані рядки Тараса Шевченка і Лесі Українки - все це є свідченням ерудиції персонажа, джерелом його духовної наснаги. Леся Українка та їі поезія згадується кілька разів, а рядки з вірша «Contra spem spero» стали назвою першої частини повісті - «На гору круту крем’яную»;

д) увесь зміст повісті показуе значущість мріі для наукових (педагогічних) відкриттів.

Учитель може зазначити, що, ймовірно, письменник свідомо вилучив із кола знайомих героя осіб, які посилили б його українськість і вивели громадську активність за прийнятні рамки. Скажімо, у Павлиші жив поет І. Шевченко, який починав шлях у літературі у 1920-х роках; у 1962 р. до нього на ювілей приїжджали П. Усенко і Д. Косарик, який деякий час очолював батьківський комітет у Павлиській школі; в Олександрійському педучилищі викладав літератор С. Гончаров, який дружив свого часу із багатьма представниками «розстріляного відродження»; завдяки краєзнавцеві I. Красюку, який розшукав невідомі документи про П. Ніщинського, В. Сухомлинський діставав дореволюційні книги 3 педагогіки [11, с. 316]; листувався В. Сухомлинський із О. Гончарем.

Найцікавіше і найцінніше в представленій книзі - це те, що Василь Олександрович постає в повісті не як видатний педагог, а насамперед як звичайна людина $з$ іiі переживаннями, тяжіннями, цілями, спрямуваннями, особливостями вдачі. Про зроблене В. Сухомлинським ми знаємо чимало і намагаємося осягнути його спадщину, а от осягнути людину - це найцікавіше, та, мабуть, цілком і неможливо. Отже, книга допомагає наблизитися до розуміння особистості педагога. Друге видання повісті припало на 1983 рік, здійснене київським видавництвом «Дніпро». Наклад книги складав 65 тис. примірників [10].

Пам'ять - жива річ. Аби вона продовжувала жити, кожне покоління має зберігати іiї і вкладати в неї нове життя! Нам ще належить осмислити морально-інтелектуальну спадщину павлиського вчителя, яка увібрала провідні тенденції розвитку педагогічного процесу майбутнього. І одним із шляхів цього осмислення $з$ точки зору нових аспектів та нових підходів $\epsilon$ залучення творів художньої літератури та інших видів мистецтва, присвячених Василеві Сухомлинському.

Розпочати розповідь (лекцію) вчитель може із зачитування спогаду доньки педагога Ольги Василівни Сухомлинської «Мій батько» [4]. Такий прийом одразу наблизить В. Сухомлинського до школярів, дасть їм змогу відчути, що педагог - це насамперед людина, батько, сім'янин, зрозуміти цінність родинних зв’язків. Доречно також буде поставити учням запитання: «А який ваш батько?», «Що б ви розповіли іншим про нього?», «Чи є у вашого тата щось спільне iз Сухомлинським-батьком?» (як варіант, відповіді на ці запитання можуть бути у вигляді есе, яке учні напишуть або наприкінці уроку, або вдома). 
Читаючи книгу, вчителеві варто враховувати час iii написання і публікації (початок 1970-х), і неминучі для тієї доби ідейні догмати, втілені у штампах «комуністичне виховання», «радянська батьківщина», «соціалістичне суспільство» тощо.

Розповідаючи учням про дитинство В. Сухомлинського, вчителеві варто наголосити на важливій ролі дідуся Омеляна і бабусі Марії у вихованні Василька, зокрема розповісти про залюбленість старенького в читання, про подаровані онуку книги, про казки, які розповідала бабуся і які запам'яталися йому на все життя. Дитячі захоплення малого Василька педагог може висвітлити через його любов до музики, вміння майстерно грати на власноруч виготовленій із бузини сопілці.

Пропонуємо вчителеві акцентувати увагу учнів на тому, що книгою життя для В. Сухомлинського була всім доступна, але не всім однаково зрозуміла українська пісня, народна казка, рідна і зарубіжна література (особливо німецька), мальовнича українська природа.

Цікавою для школярів може бути інформація про міста, де навчався Василь Сухомлинський (Кременчук і Полтава), та про його студентський побут. Зокрема, у «Повісті...»є розділ «Бенкет», який описує «врочистий» обід у день отримання студентами стипендії. На столі - склянки з чаєм, на тарілці та кількох аркушиках із зошита в косу лінію - шматки кінської ковбаси, тоненькі шматочки сала, нарізаний оселедець із цибулею, цукерки-«подушечки» і шматки свіжого чорного хліба [9, с. 27].

Тема педагогічних ідей та значення педагогічної спадщини В. Сухомлинського малодоступна учням молодших класів, але розповідь про уроки мислення серед природи, про походи вчителя і учнів до лісу, про облаштовану спільно з учнями печеру у великому яру за селом, про скляний будиночок (шкільну теплицю), про Сад Матері, кімнату Казки та ін. допоможуть молодшим школярам уявити, яким учителем був Василь Олександрович.

Зацікавить учнів і те, що В. Сухомлинський із дружиною Ганною Іванівною та двома дітьми - Ольгою і Сергієм - мешкали прямо в школі, де знаходилася його квартира, яка сьогодні є меморіальною частиною музею педагога. Можна розповісти і згаданий вище кумедний епізод з інспектором відділу освіти В. Гарбузом, який стався саме в цій квартирі. Такі відомості, доступні для розуміння і водночас цікаві дітям, демонструють суто людські якості педагога.

Інтерес у школярів викличе й інформація про те, що В. Сухомлинський спеціально для них написав понад півтори тисячі казок та оповідань, усіляко заохочував учнів Павлиської школи самим писати казки, які потім об'єднувалися у збірочки (при цьому вчителеві або комусь із учнів доречно зачитати одну із художніх мініатюр).

Завершити біографію В. Сухомлинського можна розповіддю про місце останнього спочинку педагогана пагорбі за кількасот метрів від школи, якій він присвятив усе своє життя. До речі, чимало цікавих фактів із біографії Василя Олександровича, до того ж викладених у хронологічній послідовності та цікавій формі, можна почерпнути зі статті О. В. Сухомлиської «Василь Олександрович Сухомлинський - наукова біографія» [3].

Усю інформацію про життєвий та творчий шлях видатного педагога варто супроводжувати візуальними матеріалами (види Павлиша, фото квартири Сухомлинських, пам'ятника на могилі педагога та ін.), які легко можна знайти в мережі Інтернет.
Насамкінець учителю варто наголосити, що постать Сухомлинського - це органічна єдність, взаємовплив і взаємозбагачення талантів Сухомлинського-вчителя і Сухомлинського-вченого.

Домашнє завдання вважаємо необов'язковим при вивченні біографії педагога. Краще замінити його якимось видом роботи безпосередньо на уроці, наприклад, мультимедійною презентацією «Василь Сухомлинський: фотоакценти» - демонстрацією фотографій педагога з коментарями і обговоренням.

Висновки. Таким чином, пропонований спосіб ознайомлення школярів із біографією В. Сухомлинського у формі акордів і акцентів сприятиме створенню «ефекту присутності», коли завдяки добре підготовленому, вдало підібраному та чітко структурованому матеріалу школярі відчують «присутність» педагога як близької і цікавої їм людини.

\section{СПИСОК ВИКОРИСТАНОЇ ЛІТЕРАТУРИ:}

1. Видатні педагоги. В. Сухомлинський. Я люблю Україну. Програма курсу українознавства за вибором для загальноосвітніх навчальних закладів (1-4 класи) / М. І. Чабайовська, Н. М. Омельченко, М. І. Кальчук // Початкова школа. - 2016. - № 9. - С. 39-48.

2. Казка як епічний жанр. Програма факультативного курсу для учнів 5-х класів загальноосвітніх навчальних закладів. Навчальні програми для викладання предметів варіативної складової навчального плану. Українська література. - Чернівці, 2015. - С. 4-20.

3. Сухомлинська О. В. Василь Олександрович Сухомлинський - наукова біографія / О. В. Сухомлинська // В. О. Сухомлинський у роздумах сучасних українських педагогів / упоряд. : О. В. Сухомлинська, О. Я. Савченко. - Луганськ : Вид-во ДЗ «ЛНУ імені Тараса Шевченка», 2012. - С. 14-24.

4. Сухомлинська О. Мій батько / О. В. Сухомлинська // Освіта України. - 2018. - № 39. - 8 жовтня. - С. 9.

5. Сухомлинський В. Далекосхідна [Літературні спроби] / В. Сухомлинський // Піонерія. - 1934. № 5-6. - С. 45 .

6. Сухомлинський В. О. Вибрані твори : в 5 т. T. 1. Проблеми виховання всебічно розвиненої особистості. Духовний світ школяра. Методика виховання колективу / В. О. Сухомлинський. - Київ : Радянська школа, 1975. - $654 \mathrm{c}$.

7. Василь Сухомлинський. Афоризми / Педагогічний музей України ; [уклад. О. П. Міхно, наук. консультант О. В. Сухомлинська]. - Київ : ПМУ, 2018. -104 с. (Серія «Педагогічні републікації» ; вип. 5).

8. Пинкевич А. П. Советская педагогика за десять лет $(1917$ - 1927) / А. П. Пинкевич. - М. : Работник просвещения, 1927. - 145 с.

9. Тартаковский Б. С. Повесть об учителе Сухомлинском / Б. С. Тартаковский. - Москва : Молодая гвардия, 1972. - 272 с.

10. Тартаковский Б. С. Повесть об учителе Сухомлинском. Смерть и жизнь рядом : повести / Б. С. Тартаковский. - Киев : Днипро, 1983. - 408 с.

11. Ткаченко Р. В. Сухомлинський у повісті I. Цюпи «Добротворець» / Р. В. Ткаченко // Питання літературознавства : наук. зб. - Чернівці : ЧНУ, 2014. Вип. 89. - С. 309-318.

12. Центральний державний архів-музей літератури і мистецтв України, м. Київ (ЦДАЛМ України), ф. 505, оп. 1.201, спр. 54, арк. 133, 139-141,

Дата надходження до редакиії: 06.08.2019 p. 